\title{
A MATRIX OF INTERESTS: FREUD, THE SEXOLOGISTS, AND THE LEGACY OF GREECE
}

\author{
S Kool (University of KwaZulu-Natal)
}

The use of classical scholarship in nineteenth century debates on sexuality forms the focus of this paper. It is argued that German Hellenism played a crucial role in providing Freud and German sexology with a counter discourse to the theory of degeneration, a doctrine that had steadily gained currency in the latter part of the nineteenth century. Sexology and psychoanalysis were contemporaneous areas of investigation that focussed primarily on sexuality and were considered marginalised domains that operated outside the scientific establishment of the day. This exclusion was due in part to their subject matter, but it was further compounded by their widespread rejection of degeneracy, a theory that labelled both Jews and homosexuals as deviant members of society. The complex network of association that existed between psychoanalysis and sexology in Austria and Germany is often neglected and the common ground that they shared is overlooked. This is unfortunate as they explored related fields of interest and their members were largely drawn from similar backgrounds. A significant number of these men were Jewish, a large number were homosexual or homosocial, and most of them were excellent classical scholars. Classical studies provided the foundation upon which the elite German educational system, the Gymnasium, was built, and while the Gymnasium curriculum was designed to inculcate the values of reason, selfdiscipline and idealism, it also allowed an access to the world of Greek sexuality. It is argued that the divergent attitudes towards sexuality revealed in Greek art and literature provided many of these sexual pioneers with a legitimate challenge to the medical and psychiatric definitions of normal and abnormal sexuality.

Sexology emerged in the 1860 s as a new science that took sexuality as its main focus of investigation. Although it constituted a marginal field that operated outside the mainstream disciplines of psychiatry, neurology and biology, it grew rapidly in the years between 1860 and 1933, with writers from Germany and Austria being primarily responsible for the enormous proliferation of literature on sexuality. The matrix of interests that formed around this early science affords a clearer understanding of the concerns that led Freud, along with a number of his contemporaries, to reject the concepts about sexuality that were typical of the medical and psychiatric establishment at that time. Today, psychoanalysis has effectively displaced the work of the early German sexologists and the role that 
they played in the development of psychoanalysis remains, for the most part, unacknowledged. As a result, the use of classical Greece as a counter discourse to medical science in the nineteenth and early twentieth century has received little attention.

Sexology had already been constituted as a separate form of enquiry some time before the appearance of Freud's most important contribution, The three essays on the theory of sexuality (1905) and many of the terms that we tend to identify with Freud, such as libido, component instincts, erotogenic zones, catharsis, autoerotism and narcissism were already in circulation. Thus, far from being conceived in isolation, Freud's theory of sexuality was formulated in a dialogue with sexology. It has been argued that Freud did not sufficiently acknowledge the contribution of sexology to psychoanalysis, but this position has been somewhat overstated. As early as 1888 , Freud mentions the importance of Breuer, Kaan, Forel, Moll and Krafft-Ebing to his work on hysteria. He also acknowledges the role played by Lydston, Kiernan, Chevalier, Ellis, Krafft-Ebing, Fliess, and Ulrichs in his formulation of bisexuality. ${ }^{1}$

Freud was both influenced by, and influential in, the early debates in sexology. His library contains most of the foundational texts in this field and many of these books, including Albert Moll's Untersuchungen über die Libido sexualis (1898), Krafft-Ebing's Psychopathia sexualis (1901) and Bloch's anthropological study of sexuality, Das Sexualleben unserer Zeit in seinen Beziehungen zur modernen Kultur (1907) were essential to the early development of psychoanalysis. Homosexuality was a primary focus of interest in both sexology and psychoanalysis and Freud's library includes texts by Ulrichs, Hirshfeld, Block, Eulenburg, Krauss, Rohleder, Carpenter and Ellis, all early pioneers in the study of homosexuality. The association between psychoanalysis and sexology is emphasised by Mosse (1982) who attributes the change in the way Block, Ellis and Hirschfeld theorised homosexuality to Freud. He writes:

Hirschfeld changed the manner in which homosexuality was discussed. Sigmund Freud was part of this group of sexologists whose work he knew well and who influenced his own psychoanalytic theories. Contemporaries were particularly struck by the simple, detailed and precise way in which Freud described sexual experiences, refusing to use Latin like his colleagues (Mosse 1982:239-240).

The reciprocal relationship that existed between sexology and psychoanalysis is clear in the lengthy footnote added by Freud to The three essays in 1910 in which he explicitly mentions his debt to sexology (SE 7:135). 
In turn, Freud acknowledged the importance of Hirschfeld's Jahrbuch für sexuelle Zwischenstufen unter besonderer berücksichtigung der homosexualität (Yearbook for sexual intermediate types with special consideration of homosexuality) in the development of his own theory of psychosexual development. ${ }^{2}$

These early German sexologists are seldom referenced except in fairly restricted domains such as the history of homosexuality. When they are mentioned they are often combined under the rubric of early sexologists, a convenient simplification, but one that distracts from the diversity of their contribution. The negative aspect of sexology has become a popular trope. Foucault, for example, characterised sexology as:

associated with an insistent and indiscreet medical practice, glibly proclaiming its aversions, quick to run to the rescue of law and public opinion, more servile with respect to the powers of order than amenable to the requirements of truth. Involuntarily naïve in the best of cases, more often intentionally mendacious, in complicity with what it denounced, haughty and coquettish, it established an entire pornography of the morbid, which was characteristic of the fin de siècle society. [...] It promised to eliminate defective individuals, degenerate and bastardised populations. In the name of biological and historical urgency, it justified the racisms of the state, which at the time were on the horizon. It grounded them in truth (Foucault 1998:54).

It is undeniable that sexual aberration constituted the largest area of investigation. From the outset the term degeneration, formulated by Morel in 1857, was one of the major theoretical elements of the medicalisation of the abnormal. Sexology also gained acceptance at a time when political concerns around reproduction, population and hygiene became prominent. The fin de siècle was obsessed with health and disease and the role played by heredity in the aetiology of 'abnormal' sexuality. In the wake of this obsession, elaborate taxonomies of abnormality (hysteria, masturbation, sadism, homosexuality, fetishism etc.) were constructed, together with state programs aimed at biological and medical intervention.

Having said this, a closer examination of the history of sexology dispels any conception of it as being either a coherent or a homogenous project. Instead, it is evident that it represented many different interests and agendas. Foucault tended to concentrate on sexologists such as Kaan, Campe, Lombroso, Casper-Liman, Morel, Tardieu, Carlier, Taxil, and Moreau instead of the German sexologists. This is an

First established in 1899, this journal published articles by prominent sexologists including Ulrichs, Krafft-Ebing, and Paul Brandt, it soon became one of the most referenced journals in the area of sexuality. 
important lacuna as sexology was a particularly German enterprise (Haeberle 1982:307-309; Mosse 1982:221-246). When Foucault did refer to German sexology he focused on Krafft-Ebing, the most prolific researcher at that time, but also the sexologist who most closely approximated to his negative stereotype of sexology. What is often obscured is that a large proportion of the early German sexologists provided a challenge to biological determinism, eugenics, and antifeminist movements. Instead of supporting the legal and medical establishment, they actively opposed 'public opinion' and the 'racisms of the state'.

Haeberle asserts that from its inception Sexualwissenschaft, or the science of sex, served a critical function by offering a critique of the prevailing sexual attitudes and traditional assumptions about sex:

Sexology, according to its first proponents and organizers Bloch, Hirschfeld, Eulenburg, Krauss Korber, and Rohleder, demystified the alleged unchangeable 'natural' force of sex and tried to bring it under some sort of rational control. Through their research, they hoped to provide the means for reforming the sexual life of their time. This, more than anything else, was the reason for the hostility they encountered (Haeberle 1981:276277).

By focussing on the repressive aspects of sexology, post-Foucauldians make it difficult to appreciate how often it enabled theorists, including Freud, to develop alternative, and often radical, contributions to the study of sexuality.

In the late nineteenth century sexology became a crucial, often revolutionary, force in the debates around sexuality in both scientific and legal circles. The reason for this is simple. A surprising number of sexologists were not conventional members of the German bourgeoisie, nor did they form part of the medical and psychiatric establishment. Many of them were Jewish, and many homosexual. As such, any understanding of the German sexologists must also acknowledge that their investigations into sexuality were often a reflection of their own anxieties and desires and were thus intimately related to their sexual orientation, their 'race' and their political and social status.

Haeberle comments:

it may or may not be a coincidence (and I myself attach no ulterior significance to it), but is so happens that the overwhelming majority of the sexological pioneers were Jews (Haeberle 1982:306).

A survey of German sexology confirms this. Hirschfeld, Eulenberg, Dessoir, Moll, Lowenfeld, Bloch, Breuer, Krauss, Fliess, Steinarch, Rohleder, Hirschmann, Marcuse, Hodann, von Ehrenfels, and Weininger were all Jewish, and Freud's psychoanalytical circle was comprised almost entirely of Jews. Their dominance in 
this area resulted in both sexology and psychoanalysis being categorised as examples of 'Jewish science'. Despite Haeberle attaching 'no ulterior significance' to the predominance of Jews in sexology, it is difficult to ignore this fact as if it were purely coincidental.

The early writings on sexology indicate the enormous interest directed towards the subject of homosexuality. Again, I would contend that this is not coincidental. Ulrichs, Hirschfeld, Weininger, Eulenberg, Bloch, Krauss, Brand, Friedländer, Hössli, Kertbenny, were all homosexual, and Fliess, Ehrenfels and Freud were either bisexual or 'homosocial'. Although many disagreements existed between them on the definition and aetiology of homosexuality they all made major contributions to this domain.

Jewish or homosexual, Jewish and homosexual, early sexology was represented by two of the most stigmatised groups in Germany. Rozenblit (1983:1-63) argues that to be a Jew in Germany meant that one occupied a position outside conventional middle-class society, it also placed many Jews outside the medical establishment. To be considered an invert was even more detrimental as it immediately exposed anyone so labelled to criminal charges. 'Race' and 'inversion' represented two distinct but interconnected strands that became subsumed under the medical discourse of degeneracy. The concepts of degeneration and the survival of the fittest soon became embroiled in European racism, and Mosse (1982:230) argues that the characterisation of 'inferior races' was similar in almost every respect to that applied to so-called sexual degenerates. According to Gilman not only did anti-Semitism exist in the institutions in which medicine and its related disciplines of neurology and biology were taught and practiced, 'but anti-Semitic views became a staple of the substance of medicine itself' (Gilman 1994:12). The theory of degeneracy, which classified individuals into categories of normal and abnormal, made it almost impossible for those stigmatised by medical science to practice within these institutions.

Contrary to Foucault's denouncement of sexology, many of the contributions to sexology in Austria and Germany did not fit into the neat category called by him the 'medico-psychiatric discourses on sexuality'. The reason for this is apparent to anyone conversant with the dominant scientific discourse at the time. Biological determinism and associated theories of degeneracy (critical concepts for the establishment of psychiatry as a new scientific discipline that specialised in mental pathology) lent support to sexual, political and cultural discrimination. It is for this reason that psychiatry was so often considered an integral agent of social control.

The new science of eugenics which was established to provide criteria for genetic progress through the regulation of procreation and biological heredity, meshed remarkably well with a neurological theory of degeneration. This led to 
both Jews and homosexuals being accused of undermining the foundations of a healthy state.

Biale claims:

Both popular anti-Semitic culture and the dominant medical opinion of the fin de siècle considered Jews to be neurologically diseased people whose pathology was inextricably linked to perversion and hypersexuality (Biale 1997:274).

In a short period homosexuality also became an important topic and more papers were written on this subject than on any other area within the field of sexology. Both 'racial inferiority' and 'inversion' were held up as examples of biological degeneration and attributed to 'inbreeding', sexual dissipation and incest.

The fin de siècle was saturated with this discourse. The major proponent of this theory was Max Nordau whose famous treatise Degeneration (1895) was exclusively couched in the language of psychiatry. Nordau considered hysteria, neurasthenia, homosexuality, even decadence in art and literature to be the result of biological degeneration, and he identified Vienna, the city in which Freud lived and practiced, as the epicentre of mental, emotional and biological decadence.

Sulloway (1979:422) notes that between 1890 and 1905 Freud underwent a profound change that resulted in him moving his position away from neurology and towards psychology. He links Freud's emphasis on the primacy of early experience over biology to his rejection of 'degeneracy'. Looking carefully at Freud's texts it soon becomes evident how often he places the terms perversion and degeneration in inverted commas in order to distance himself from this terminology. His opposition to psychiatry is plainly expressed in his Introductory lectures on psychoanalysis:

Psychiatry gives names to different obsessions but says nothing further about them. On the other hand it insists that those who suffer from these symptoms are 'degenerates'. This gives small satisfaction; in fact it is a judgment of value - a condemnation instead of an explanation (SE 16:260).

Freud was not alone in his criticism of psychiatry; most Jewish and homosexual sexologists linked the concept of degeneracy with psychiatry and accordingly rejected the academic and scientific institutions that supported this position. Deracinated from these 'legitimate institutions', many early sexologists found support for their scientific theories by using alternative intellectual frameworks. The most important of these was Hellenism.

There is abundant research to indicate that Freud was deeply immersed in classical Bildung and those who are acquainted with psychoanalysis are aware of how frequently Freud used the legacy of Greece to conceptualise, legitimate and 
expand his theory. So, however, did many other sexologists writing at the time. Ulrichs, Hössli, Friedländer, Roeher, Brandt, Eulenburg, Bloch, and Hirschfeld were all excellent classicists and the fertile relationship that existed between sexology and classical studies is confirmed by the number of papers dealing with classical themes that appeared in journals such as the Jahrbuch für sexuelle Zwischenstufen, Der Eigene and Anthropophteia.

This, again, is not coincidental. Winckelmann's 'rediscovery' of Greece in the eighteenth century underpinned the philosophy of Bildung and the Gymnasium curriculum with its emphasis on Latin and Greek studies was considered a prerequisite for a University education. As a result Germany became moulded to the ideas and images of the classical world (Butler 1958:3-8; Marchand 2003:3-35). In a society riddled with anti-Semitism, German Hellenism still enshrined the ideals of humanism and democracy. For this reason, and because it provided an opportunity to assimilate into the dominant culture, one finds that a disproportionate number of Jews attended the Gymnasium. This elite education allowed every Gymnasium scholar, no matter how different his background, to study the Greek classics as well as the poetry of Goethe, Lessing, Schiller and Heine. Beller (2000:148-155) argues that for those Jews wishing to abandon the 'baggage of Hebraism' it was much easier to embrace the myths and writings of Greek antiquity and the philhellenic literature of Germany than it was to adopt the more medieval constructions of Christianity and the Nordic myths of German nationalism.

Paradoxically, the idealisation of Greece meant that Germany and Austria also revered a culture that condoned the ideals of homosexuality. Winckelmann's ideology, so foundational to the German educational system, did not automatically provide support for normative masculinity. Indeed, his complex, homoerotic reading of classical Greek art offered a challenge to the nineteenth century ideal of procreative sex. It is not surprising therefore to find that those who rejected the vocabulary of degeneracy almost universally appealed to classical Greece for support and legitimation.

For individuals such as Ulrichs, Hössli, Hirschfeld, Brandt, Bloch and Freud, classical authors provided a legitimate challenge to the classification systems of perversion. Although the sexual act was placed under an extremely careful regimen in antiquity, the Greeks never shared the deep suspicion that Christianity directed towards the body. The depiction of explicitly sexual acts, particularly on Greek pottery, also called into question the reception of Winckelmann's theory of Greek art. In the nineteenth century classical Greece still operated as an ethical and aesthetic compass and the erotic themes represented in art and literature became an area of intense speculation and controversy. Nowhere was this disjunction more apparent than in the institution of paiderastia, a form of 
pedagogical mentorship designed to advance the socialisation of young boys into the elite male world of the symposium and athletics (Hubbard 2003:12). In one of the most important texts in the area of Greek 'homosexuality', Plato's Symposium, the different speakers articulate a diversity of opinion regarding the conduct and nature of male/male relationships. Hubbard (2003:7) argues that the sexual behaviour in Greece and Rome was irreducible to any single paradigm of same gender interaction, and as a consequent judgements relating to nature or conduct of homosexuality were far from uniform. These ambiguities are also reflected in the terminology coined in early sexology for example, 'sexual invert', 'Urning', 'intermediate', 'contrary sexuality'; 'androgyne', 'third sex' and 'homosexual'. These different terms and meanings soon opened up heated debates as to whether homosexuality was acquired, inherited or simply a natural continuum of normal sexual behaviour.

Like Freud, most of the German sexologists, including Löwenfeld, Ulrichs, Hirschfeld, Bloch, and Rohleder rejected the conception of sexual inversion as degeneracy. While Hirschfeld came conceptually closer to Ulrichs' idea of a 'third sex' and assumed a congenital aetiology for homosexuality, others, including Freud and Bloch cited Greek paiderastic relationships as an argument against an innate predisposition to homosexuality. Friedländer, Hössli and Weininger rejected a congenital cause for homosexuality, but they also criticised the 'feminising' elements contained in Hirschfeld's theory. For these sexologists, a Dorian model of masculine, homoerotic male bonding, based upon Bethe's study of paiderasia published in 1907, provided an example to be emulated.

Greek and Roman mythology, the lyrical poets, dramatists and artists of antiquity often emphasised the importance of sexual desire and sexual pleasure, and the discoveries at Herculaneum and Pompeii gave visual testimony to the erotic world of Greece and Rome. It does not surprise to find that among Freud's collection of antiquities are a number of phallic objects from his sojourns in Naples as well as a fragment of a painted wall from Pompeii. Such artefacts inspired Freud to assert that 'the ancients glorified the instinct', and that contrary to the emphasis placed on heterosexual procreation, classical Greece regarded sexual desire as something quite distinct from biological reproduction. Foucault (1998:97) once asked whether the practice of scientia sexualis was not simply an extraordinary form of ars erotica - a Western sublimated version of the lost art of love. Looking at the work of some of the early sexologists and their engagement with Greece it is clear that they were not simply conducting scientific investigations into sexuality but were writing a 'poetics of desire'. Many of the sexologists published articles, books and poetry founded on Greek and Roman antiquity. Notable examples are Hössli's Eros. Die Männerliebe der Griechen (1836;1838); Friedlander's Renaissance des Eros Uranios (1904) and Ulrichs' Forschungen 
über das Räthsel der mannmännlichen Liebe (1898). The most prolific and vocal of these sexologists was, however, Magnus Hirschfeld, who published over forty books on homosexuality and as editor of the Jahrbuch für sexuelle Zwischenstufen did more than anyone else to open up investigations into homosexuality. Ellis (1930:1-64) cites numerous examples in his discussion of paiderastia drawn from this Journal and notes that it 'contains many studies bearing on the ideal and aesthetic aspects of homosexuality' based on early Greek civilisation.

Despite disagreements on the nature of homosexuality, many of the early German sexologists wrote books, articles and pamphlets that were aimed at changing conventional attitudes towards various forms of non-reproductive sex. This is the reason why such a powerful sex reform movement emerged in Germany in the nineteenth century. Hirschfeld was by far the most active campaigner, and as the President of the Wissenschaftlich-humanitäre Komitee (in alliance with the German left) he played a prominent role in defending the interests of homosexuals, lesbians and women's groups, lobbied for both women's rights and homosexual rights, and openly challenged Paragraph 175 which made sodomy a criminal act.

Although Freud never politically campaigned for homosexual rights, his statements are a public record of his position:

Psychoanalytic research is most decidedly opposed to any attempt at separating off homosexuals from the rest of mankind as a group of special character. By studying sexual excitations other than those that are manifestly displayed, it has found that all human beings are capable of making a homosexual object-choice and have in fact made one in their unconscious. Indeed, libidinal attachments to persons of the same sex play no less a part as factors in normal mental life, and a greater part as a motive force for illness, than do similar attachments to the opposite sex (SE 7:145).

Freud rejected the idea that inversion indicated nervous degeneracy; more generally he rejected the psychiatric concept of inversion as pathological. Instead he made bi-sexuality fundamental to his theory of psycho-sexual development. This position owed a lot to Fliess' controversial theory of bi-sexuality, but his understanding of bi-sexuality was further reinforced by his knowledge of sexuality in the ancient world.

It is clear that in Greece, where the most masculine men were numbered among the inverts, what excited a man's love was not the masculine character of a boy, but his physical resemblance to a woman as well as his feminine mental qualities - his shyness, his modesty and his need for instruction and assistance. As soon as the boy became a man he ceased to be a sexual object for men and himself, perhaps, became a lover of boys. In 
this instance, therefore, as in many others, the sexual object is not someone of the same sex, but someone who combines the characters of both sexes; there is, as it were, a compromise between an impulse that seeks for a man and one that seeks for a woman, while it remains a paramount condition that the object's body (i.e. genitals) shall be of a masculine sexual nature. Thus the sexual object is a kind of reflection of the subject's own bisexual nature (SE 7:144).

Freud's understanding of bisexuality in the ancient world is surprisingly modern and in line with contemporary theorists such as Cantarella (2002:212) and his familiarity with Aristophanes myth of the three sexes in the Symposium, (which proposes that there are three genders - male, female and an androgynous gender that is a combination of male and female) further reinforced his theory of bisexuality.

An essential element of the Athenian institution of pederasty was the acceptance of both homosexual and heterosexual expressions of sexuality. For Freud, as for many of the early sexologists, this acceptance demonstrated that homosexuality could not be simply dismissed as perversion, but must be understood in the light of both individual and societal choice. Same-gendered love between males in the ancient world has recently become an exceptionally contested domain (Davidson 2001:3-51; Hubbard 1998:48-78; Thorp 1992:54-61), but having said this, the institution of pedagogical pederasty is generally perceived to conform to an age-differential model in which a young boy (eromenos) from an elite family is initiated into sexual and social manhood by an older man (erastes). Freud's engagement with classical scholarship alerted him to the fact that men in antiquity were not required to restrict themselves to either women or boys, and that sexuality was conceived to be fluid and not necessarily fixed by biology. This allowed him to argue that it is possible to choose a sexual object that is independent of gender considerations and that this 'freedom to range equally over male and female objects' (SE 7:145) is the original basis of our sexuality. By rejecting a congenital aetiology for homosexuality, Freud operated with a concept of sexuality that differed from many of his contemporaries who believed that homosexuality was innate. This position placed him very close to queer theorists of today who argue that sexuality is dynamic and fluid and not constrained by gender.

Freud's excellent grasp of homosexual relations in antiquity is further demonstrated by his awareness that these relationships were strongly demarcated by age and that the educational or initiatory aspect was paramount to this institution. He was also cognisant, despite many arguments to the contrary in nineteenth century literature, that homosexuality was not the sole preserve of 
effeminate men, and pointed out that in antiquity 'the most masculine men were numbered among the inverts' (SE 7:144). This knowledge allowed him to rise above the stereotypes of his age and debunk many of the misconceptions around homosexuality.

The failure to position Freud within early sexology, especially in terms of the appeal to classical Greece, leads to a neglect of the importance of Greek antiquity in Freud's theory of sexuality. This despite the fact that in The three essays (1910), Freud gives the Greek concept of sex a foundational role:

The most striking distinction between the erotic life of antiquity and our own no doubt lies in the fact that the ancients laid the stress upon the instinct itself, whereas we emphasise its object. The ancients glorified the instinct and were prepared on its account to honour even an inferior object; while we despise the instinctual activity in itself, and find excuses for it only in the merits of the object (SE 7:149).

Freud's famous argument that instinct and object are 'merely soldered together' and that we should 'loosen the bond that exists in our thoughts between instinct and object' (SE 7:148) is therefore a radical endorsement of Greek sexuality. In elevating the sexual instinct of the ancients to the primary drive Freud relegated the object to one of secondary importance. This allowed him to argue that because the nature of the instinct is not exclusively bound to any particular object it is possible that in 'surprisingly numerous individuals, the nature and importance of the sexual object recedes into the background' (SE 7:149). All human beings are bi-sexual, according to Freud, and they are therefore capable of making either a heterosexual or a homosexual choice.

It is interesting to compare Freud's theory with that of Krafft-Ebing, one of the most influential Austro-German psychiatrists at this time. In the first sentence of Psychopathia sexualis (1886), one of the classic works on sexual aberration, Krafft-Ebing claims that 'the propagation of the human race is not left to mere accident or the caprices of the individual, but is guaranteed by the hidden laws of nature which are enforced by a mighty, irresistible impulse' (Krafft-Ebing 1965:1). Like most of his psychiatric contemporaries, Krafft-Ebing believed that any expression of the sexual instinct that is not directed towards reproduction should be regarded as unnatural and perverse. Freud rejected this opinion on the first page of The three essays when he states that inversion should not be regarded as degenerate because it is found in people who exhibit no other serious deviations from the normal and it also existed among peoples of antiquity at the height of their civilisation.

Because ancient Greece became a major referent in positions that supported divergent sexuality, those who adopted contrary positions were forced to reject 
'Greece' as the pinnacle of Western civilisation. An excellent example of this position is to be found in Krafft-Ebing's Psychopathia sexualis. Krafft-Ebing attributed the 'monstrous excesses of sexual life' that he found in Greek art and literature to 'moral decay' and argued that sexual deviance is always traceable to psycho-pathological or neuro-pathological conditions of the nations involved:

In comparing the various stages of civilisation it becomes evident that, despite periodical relapses, public morality has made steady progress, and that Christianity is the chief factor in this advance. We are certainly far beyond sodomitic idolatry, the public life, legislation and religious exercises of ancient Greece, not to speak of the worship of Phallus and Priapus, in vogue among the Athenians and Babylonians, or the Bacchanalian feasts of the Romans and the privileged position held by the courtesans of those days. There are stagnant and fluctuating periods in this slow progress, but they are only like the ebb and flood-tide of sexual life in the individual. The episodes of moral decay always coincide with the progression of effeminacy, lewdness and luxuriance of the nations. These phenomena can only be ascribed to the higher and more stringent demands which circumstances make upon the nervous system. Exaggerated tension of the nervous system stimulates sensuality, leads the individual as well as the masses to excesses, and undermines the very foundations of society, and the morality and purity of family life. The material and moral ruin of the community is readily brought about by debauchery, adultery and luxury. Greece, the Roman Empire, and France under Louis XIV and XV, are striking examples of this assertion. In such periods of civic and moral decline the most monstrous excesses of sexual life may be observed, which, however, can always be traced to psycho-pathological or neuro-pathological conditions of the nations involved (Krafft-Ebing 1965:4).

That this statement appears almost immediately, on page four of Psychopathia sexualis, is an indication of how essential it was to challenge Greece as a trope in any debate concerned with sexuality. In opposition to Krafft-Ebing's diatribe, Freud used Greece as an example of 'normal' sexuality and argued that it is the restrictions placed on the sexual instinct by 'public morality' that so often cause illness, neurosis, obsession and hysteria. In contrast to the normalising tendencies that are so often attributed to Freud, it is clear that Freud's theory of sexuality rejected fixed biological drives, thus making sexuality psychological, bisexual and more flexible. Unlike Krafft-Ebing, who considered Christianity the principle factor in the steady advance towards moral and psychological progress, Freud attributed our discontent - our displeasure - to the victory of Christendom over 
other religions, and to the low estimation placed upon earthly life by Christian doctrine (SE 21:87).

\section{The Eros of the ancients}

Boswell (1991:23) claims that there is still no essential agreement in the scientific community about the nature of sexuality, and that it is still an open question as to whether humans are 'homosexual' or 'heterosexual' or 'bisexual' by birth, by training or by choice. He suggests that this lack of scientific agreement explains why today, as in the past, the ancient tract on love, Plato's Symposium still remains the locus classicus for discussions on sexuality. Before Karl Maria Benkert invented the term 'homosexual' in 1869, Karl Ulrichs made use of the language of the Symposium to speak about male / male love. He coined the term Urning (the allusion is to Uranos in Plato's Symposium) to describe a man who is sexually attracted only to men. He advocated the freedom of sexual choice and modelled a cult of Uranism on Pausanias' praise of the Eros of Celestial Aphrodite, a love that is goverened by strict conventions that 'impels a lover to pay a great deal of serious attention to the question of virtue' as well as for the boy who is the object of the lovers affection (Plato 1994:19). Ulrichs theorised a biological third sex, 'anima muliebris in corpore virili inclusa, ${ }^{3}$, and while he argued that homosexuality was a biological condition, he rejected the label of pathology that was so frequently applied to it. This position was influential in early sexology and his terminology was extended by Wilhelmine classicists such as Westphal, Hössli and Hirschfeld and it was also adopted in England by Symonds and Carpenter.

Freud found Ulrichs theorising crude, especially his acceptance of a biological aetiology for homosexuality:

The theory of bisexuality has been expressed in its crudest form by a spokesman of the male inverts: 'a feminine brain in a masculine body'. But we are ignorant of what characterises a feminine brain. There is neither need nor justification for replacing the psychological problem by the anatomical one (SE 7:142).

Despite his rejection of Ulrichs' work, Freud also drew extensively on Plato's Symposium. He first mentions this text in The three essays (1905) and returned to it many years later in his discussion on the origin of sexuality in Beyond the pleasure principle in 1920 (SE 18:57-58). Freud saw in Plato's Symposium, and Aristophanes' speech in particular, a number of similarities to his own bisexual theory of sexuality. Aristophanes presents his audience with a range of sexual

'A woman's soul in a man's body'. 
choices. According to him, sexual satisfaction in heterosexual relationships leads to procreation; homosexuality, on the other hand, defuses sexual tension 'so that people could relax, get on with their work and take care of other aspects of life' and women 'who are, offcuts from the female gender' incline towards women (Plato 1994:28). Aristophanes' belief in a variety of sexual experiences is very closely reflected in Freud's acceptance of a bi-sexual predisposition in human sexuality. Freud writes:

Man is an animal organism with (like others) an unmistakably bisexual disposition. The individual corresponds to a fusion of two symmetrical halves, of which, according to some investigators, one is purely male and the other female. It is equally possible that each half was originally hermaphrodite (SE 21:105).

This statement closely corresponds to Aristophanes speech in the Symposium:

The starting-point is for you to understand human nature and what happened to it. You see, our nature wasn't originally the same as it is now: it has changed. Firstly, there used to be three human genders, not just two — male and female — as there are nowadays. There was also a third, which was a combination of both the other two (Plato 1994:25).

Freud's familiarity with classical Greek literature allowed him to view the 'cultural requirement' placed upon the erotic life of the individual as limiting and detrimental to psychological health. Civilisation he writes, does not like sexuality as a source of pleasure in its own right and only tolerates it because there is so far no substitute for it as a means of propagating the human race. These restrictions on sexual pleasure deny sexual fulfilment to a large number of people who often become neurotic because they cannot tolerate the frustration that has been imposed upon them in the service of cultural ideals. In releasing sexuality from innate biological impulses, Freud suggests that sexuality is socially and psychologically constructed and his acceptance of the 'enlarged' sexuality of the ancients made it possible for him to construct a theory that was broad enough to encompass nongenital pleasure such as kissing, looking, touching, fantasising and other polymorphous expressions of erotic desire that were not essentially directed towards reproductive sex.

In the 1920 preface to the fourth edition of The three essays Freud writes:

And as for the 'stretching' of the concept of sexuality which has been necessitated by the analysis of children and what are called perverts, anyone who looks down with contempt upon psycho-analysis from a superior 
vantage-point should remember how closely the enlarged sexuality of psycho-analysis coincides with the Eros of the divine Plato (SE 7:134).

Freud's appeal to Plato to substantiate psychoanalysis, instead of to science, may appear incongruent, but even today this terrain is scientifically debated and ideologically constructed. Modern historians in the field of sexuality, including Foucault, Boswell, and Halperin, have all used the Symposium to argue their respective positions. That it still appears to be useful in debates between essentialists and social constructionists suggests that, in the field of sexuality, the Symposium still supports relevant and divergent readings concerning homosexual identity.

In closing, it is important to return to another area in which Freud's theory of sexuality anticipates modern writers on classical Greece. Halperin writes:

In classical Athens, then, sexual partners came in two different kinds, not male and female but active and passive, dominant and submissive. The relevant features of a sexual object were not so much determined by a physical typology of genders as by the social articulation of power. That is why the currently fashionable distinction between homosexuality and heterosexuality had no meaning for the classical Athenians (Halperin 1989:50).

This polarisation of the sexual partners into the categories of penetrator and penetrated as well as a corresponding division of sexual roles into 'active' and 'passive' was first articulated by Dover in 1978 in his ground-breaking work on Greek homosexuality. His analysis of Greek homosexuality was later deployed by Foucault in his three volume text on the history of sexuality, and their work is now considered a cutting-edge view of modern homosexuality. In discussing Dover's formation of this new model of Greek homosexuality, Davidson states: 'There have been no dramatic new finds, no coded diaries deciphered, yet the modern view of Greek love is almost the exact opposite of the view that prevailed in the nineteenth century and which lingered on until the 1960s: from essentially 'pure', to pure sex' (Davidson 2001:5). Davidson statement suggests that Dover's theory came out of the blue and that there was very little concrete classical scholarship to account for this radical overturn of the traditional nineteenth century concept of Greek love. Dover was, however, deeply influenced by Freudian psychoanalysis and it intriguing to consider that this controversial paradigm may have been influenced by his reading of Freud's Three essays on sexuality (1905). Dover's position on homosexuality closely parallels Freud's analysis, and this position was later endorsed, following Dover's work, by Foucault and his admirers. Freud, Dover and Foucault all support the following thesis; first, that it is our preference of object 
(heterosexual or homosexual) that marks the essential difference between modern sexuality and that of the ancient Greeks, and secondly, that for the Greeks it is the position of subject (active or passive) that dominates the discourse on sexual conduct. Freud wrote:

It is essential to understand clearly that the concepts of 'masculine' and 'feminine', whose meaning seems so unambiguous to ordinary people, are among the most confused that occur in science. It is possible to distinguish at least three uses. 'Masculine' and 'feminine' are used sometimes in the sense of activity and passivity, sometimes in a biological, and sometimes, again, in a sociological sense. The first of these three meanings is the essential one, and the one most serviceable in psychoanalysis (SE 7:219).

The sexual act always remained for Freud one of dominance and submission; but this was not necessarily a gendered position, and as such, I believe that he prefigured both Dover's and Foucault's analysis of Greek sexual relations.

\section{Conclusion}

Freud was fully aware of the importance of Greek antiquity in early sexology, not only as an instrument of legitimation, but also as a means of expressing ideas without recourse to the prevailing models of degeneracy. Looking at Freud and the early sexologists it becomes apparent that, however flawed their endeavours, they created a unique space in which they could explore new ways to conceptualise and articulate the desires, anxieties and frustrations of sexual life. In sexology, as in psychoanalysis, classical Greece played a vital role in the debates concerned with sexuality. Particularly in the realm of the homosexuality, now as in the past, classical texts opened the way to formulating alternative models of gender and sexuality.

\section{BIBLIOGRAPHY}

Beller, S 2000. Vienna and the Jews 1867-1938. A cultural history. Cambridge: Cambridge University Press.

Biale, D 1997. The discipline Sexualwissenschaft emerges in Germany, creating divergent notions of the sexuality of European Jewry. In Gilman, S L, \& Zipes, J (eds.) Yale companion to Jewish writing and thought in German culture 1996-1997. New Haven: Yale University Press.

Boswell, J 1991. Revolutions, universals, and sexual categories. In Bauml M, Duberman M Vicinus M, \& Chauncey G Jr, (eds.), Hidden from history: Reclaiming the gay and lesbian past. Harmondsworth: Penguin Books Ltd. Butler, E M 1958. The tyranny of Greece over Germany. Boston: Beacon Press. 
Cantarella, E 2002. Bisexuality in the ancient world. New Haven and London: Yale University Press.

Davidson J 2001. Dover, Foucault and Greek homosexuality: Penetration and the truth about sex. Past \& Present 170:3-51.

Dover, K 1978. Greek homosexuality. London: Duckworth.

Ellis, H 1930. Studies in the psychology of sex, vol. 2 Sexual inversion. Philadelphia: F A Davis Company.

Foucault, M 1998. The history of sexuality. The will to knowledge. Translated by Hurley, R. Harmondsworth: Allen Lane.

Foucault, M 1986. The history of sexuality. The use of pleasure. Translated by Hurley, R Harmondsworth: Viking.

Freud, S 1905. Three essays on the theory of sexuality. SE 7:125 - 245.

Freud, S 1916-1917. Introductory lectures on psychoanalysis. SE 16: 243-448.

Freud, S 1920. Beyond the pleasure principle. SE 18:7 - 64.

Freud, S 1926. The question of lay analysis. SE 20:183 - 258.

Freud, S 1930. Civilization and its discontents. SE 21:64 - 145.

Gilman, S L 1994. The case of Sigmund Freud. Medicine and identity at the fin de siècle. Baltimore and London: The John Hopkins University Press.

Haeberle, E J 1981. Swastika, pink triangle and yellow Star: The destruction of sexology and the persecution of homosexuals in Nazi Germany. In The Journal of Sex Research 17.4:270-287.

Haeberle, E J 1982. The Jewish contribution to the development of sexology. In The Journal of Sex Research 18.4:305-323.

Halperin, D M, Winkler, J J, \& Zeitlin F I (eds.) 1989. Before sexuality. The construction of erotic experience in the ancient Greek world. Maine: Princeton University Press.

Hubbard, T K 1998. Popular perceptions of elite homosexuality in Classical Athens. Arion 98:48-78.

Hubbard, T K 2003. Homosexuality in Greece and Rome. A sourcebook of basic documents. Berkely and Los Angeles: University of California Press, Ltd.

Krafft-Ebing, R 1965. Psychopathia sexualis. London: Mayflower-Dell.

Marchand, S L 2003. Down from Olympus. Princeton, New Jersey: Princeton University Press.

Mosse, G L 1982. Nationalism and respectability: Normal and abnormal sexuality in the nineteenth century. Journal of Contemporary History 7.2: 221-246.

Nordau, M 1920. Degeneration. London: William Heinemann.

Plato 1994. Symposium. Translated by Waterfield, R. Oxford: Oxford University Press.

Rozenblit, M L 1983. The Jews of Vienna: 1867-1914. Assimilation and identity. New York: State University of New York Press. 
Sulloway, F 1979. Freud, biologist of the mind: Beyond the psychoanalytic legend. New York: Basic Books.

Thorp J 1992. The social construction of homosexuality. Phoenix 46.1:54-61. 